\title{
New Insights Into Permeation of Large Cations Through ATP-Gated P2X Receptors
}

\author{
Laurie Peverini, Juline Beudez, Kate Dunning, Thierry Chataigneau and Thomas Grutter* \\ CNRS, CAMB UMR 7199, Équipe de Chimie et Neurobiologie Moléculaire, Université de Strasbourg, Strasbourg, France
}

The permeability of large cations through the P2X pore has remained arguably the most controversial and complicated topic in P2X-related research, with the emergence of conflicting studies on the existence, mechanism and physiological relevance of a so-called "dilated" state. Due to the important role of several "dilating" P2X subtypes in numerous diseases, a clear and detailed understanding of this phenomenon represents a research priority. Recent advances, however, have challenged the existence of a progressive, ATP-induced pore dilation, by demonstrating that this phenomenon is an artifact of the method employed. Here, we discuss briefly the history of this controversial and enigmatic dilated state, from its initial discovery to its recent reconsideration. We will discuss the literature in which mechanistic pathways to a large cation-permeable state are proposed, as well as important advances in the methodology employed to study this elusive state. Considering recent literature, we will also open the discussion as to whether an intrinsically dilating P2X pore exists, as well as the physiological relevance of

OPEN ACCESS

Edited by:

Joe Lynch,

The University of Queensland, Australia

Reviewed by: Toshi Kawate, Cornell University, United States Elsa Fabbretti, University of Trieste, Italy

*Correspondence: Thomas Grutter grutter@unistra.fr

Received: 29 May 2018 Accepted: 13 July 2018 Published: 31 July 2018

Citation:

Peverini L, Beudez J, Dunning K, Chataigneau T and Grutter T (2018) New Insights Into Permeation of Large Cations Through ATP-Gated P2X Receptors.

Front. Mol. Neurosci. 11:265. doi: 10.3389/fnmol.2018.00265 such a large cation-permeable pore and its potential use as therapeutic pathway.

Keywords: LGICs, P2X receptors, dilation, spermidine, ion permeation

\section{INTRODUCTION}

For most ion channels, ion selectivity remains stable over time once the pore has opened, allowing small metal ions, such as $\mathrm{Na}^{+}, \mathrm{K}^{+}$and $\mathrm{Ca}^{2+}$ to flow across the cell membrane. However, a few channels, namely TRPV1 (Chung et al., 2008), TRPV2 (Nabissi et al., 2013; Zubcevic et al., 2018), TRPA1 (Banke et al., 2010), acid-sensing ion channels (ASICs; Lingueglia et al., 1997; de Weille et al., 1998) and ATP-gated P2X receptors (Khakh and Lester, 1999; Virginio et al., 1999a) exhibit a striking increase in their permeability to larger cations, such as fluorescent dyes or synthetic organic molecules. This phenomenon was initially thought to occur through a time-dependent change of their ion selectivity upon repeated stimulation, a process known as "pore dilation." However, recent advances have challenged the idea of a slow dynamic change in ion selectivity (Puopolo et al., 2013; Li et al., 2015). In the case of P2X receptors, for which this phenomenon was first described several decades ago, pore dilation has failed to be unanimously accepted due to the increasing emergence of conflicting studies, and alternative mechanisms have been tentatively suggested (Jiang et al., 2005; Rokic and Stojilkovic, 2013; Wei et al., 2016). Given the importance of these ligand-gated ion channels in various physiological and pathological processes, including inflammation and neuropathic pain (Khakh and Alan North, 2006; Abbracchio et al., 2009; Khakh and North, 2012; Lemoine et al., 2012; Bernier et al., 2017), 
a clear and detailed understanding of this unusual process at the molecular level is of utmost importance.

First cloned in 1994 (Brake et al., 1994; Valera et al., 1994), the family of P2X receptors is comprised of seven different subunit subtypes (P2X1-P2X7). A functional receptor is composed of three subunits, which are assembled as homoor heterotrimers (Saul et al., 2013). Each subtype monomer shares a common architecture: two transmembrane domains (named TM1 and TM2) linked by a large, multi-glycosylated and disulfide bridge-containing extracellular domain, and intracellular C- and N-termini (Kawate et al., 2009; Figure 1). There are three ATP-binding sites which are found within the extracellular domain, positioned in cavities at the interface of adjacent subunits (Chataigneau et al., 2013; Habermacher et al., 2016a). In response to ATP binding, P2X receptors cycle between a number of different allosteric conformational states for which X-ray structures are now available (Kawate et al., 2009; Hattori and Gouaux, 2012; Mansoor et al., 2016; Figure 1). Initial ATP binding to the resting, closed channel state triggers a conformational change, resulting in the displacement of all six transmembrane helices and subsequent opening of the transmembrane pore ( $\mathrm{Li}$ et al., 2008; Kracun et al., 2010). This transition (termed "gating") usually takes place on the millisecond time scale and allows the small metal cations $\mathrm{Na}^{+}, \mathrm{K}^{+}$and $\mathrm{Ca}^{2+}$ to pass through the open pore (sometimes called $\mathrm{I}_{1}$ state) according to their electrochemical gradient (North, 2002). Sustained application of ATP then leads to the inactivation of the pore (with the exception of $\mathrm{P} 2 \mathrm{X} 7$ ), a process called desensitization, in which ion flux is terminated despite the fact that ATP remains bound to the receptor. ATP dissociation from these states reverts the pore to the initial closed state, from which the receptor is able to undergo further gating cycles upon re-activation (Figure 1).

To account for the gradual increase of permeability to larger cations, several mechanistic pathways linked to the P2X gating cycle have been proposed (Jiang et al., 2005; Rokic and Stojilkovic, 2013; Wei et al., 2016). For one of these routes, a putative dilated state (called $\mathrm{I}_{2}$ state) corresponding to a progressive pore expansion of the open $I_{1}$ state following sustained ATP application has been suggested (Khakh and Lester, 1999; Virginio et al., 1999a; Figure 1). However, recent studies have seriously challenged this pore dilation hypothesis, by demonstrating that this phenomenon is rather an artifact of the method used to measure ion permeability change. In this review, we will discuss briefly the historical emergence of the controversial dilated state in the P2X family, as well as the recent important advances in the methodology employed that have led to the reconsideration of pore dilation. Finally, we will open the discussion to new physiological and therapeutic perspectives.

\section{BRIEF HISTORY OF THE INCREASE OF PERMEABILITY}

The ability of ATP to permeabilize membranes from different cells, such as mast cells, macrophages and transformed fibroblasts, was first discovered in the late 70s by demonstrating that the membrane permeability of cells gradually increases with increasing concentrations of ATP (Cockcroft and Gomperts, 1979). Besides small inorganic cations, larger organic molecules, such as carboxyfluorescein (376 Da), ethidium bromide (394 Da), lucifer yellow $(444 \mathrm{Da})$ and fura-2 $(636 \mathrm{Da})$ were also shown to be able to cross membranes following ATP application. However, solutes of higher molecular weight, such as Trypan Blue (872 Da), Evans Blue (961 Da) and inulin (more than $5000 \mathrm{Da}$ ) did not permeate the membrane (Steinberg et al., 1987; Steinberg and Silverstein, 1989), suggesting that molecules exceeding a certain radius cannot pass. At this point in time, the protein responsible for this behavior was unknown, and additionally, the observed "pore formation" features largely varied according to the cellular subtypes studied (Heppel et al., 1985).

Following these observations, and the discovery of ATP-activated purinergic receptors (P2X and P2Y; Burnstock, 1990), the passage of such large molecules across cell membranes was attributed to the fact that those cell types, in particular immune cells, express an unusual P2 receptor with an apparently non-selective pore. This was initially classified as the P2Z receptor: the "pore-forming" protein was thus named (Gordon, 1986; Abbracchio and Burnstock, 1994). P2Z receptors were then extensively studied for their ability to allow the permeation of large organic molecules into macrophages through a "macropore" (Nuttle and Dubyak, 1994), leading to cytolysis (Di Virgilio, 1995). The link with a putative P2Xrelated mechanism arose from the identification of the close proximity between $\mathrm{P} 2 \mathrm{Z}$ receptor and $\mathrm{P} 2 \mathrm{X}$ family receptor sequences. This similarity led to the re-classification of $\mathrm{P} 2 \mathrm{Z}$ as the P2X7 receptor subtype (Surprenant et al., 1996). A few years later, two seminal articles reported that other P2X subtypes, the P2X2 and P2X4, also exhibit a striking increase in the permeability of large cations following several seconds of ATP application (Khakh et al., 1999; Virginio et al., 1999b). The concept of P2X "pore dilation" was born and multiple research groups have since confirmed and extended the concept to homomeric and heteromeric receptors (e.g., P2X2/3 and $\mathrm{P} 2 \mathrm{X} 2 / 5)$ expressed either in recombinant systems or in native tissues (Khakh et al., 1999; Virginio et al., 1999b; Yan et al., 2008; Compan et al., 2012; Browne et al., 2013). However, certain P2X subtypes, namely P2X1 and P2X3 which are fast desensitizing receptors, were classified as "non-dilating" channels as there was no evidence for an apparent increase in the permeability to large cations. Moreover, distinctive behaviors have been observed for P2X7 receptor splice variants, of which there are nine in humans, classified from $\mathrm{P} 2 \mathrm{X} 7 \mathrm{~B}$ to P2X7J, and four in rodents (P2X7B, P2X7C, P2X7D and $\mathrm{P} 2 \mathrm{X} 7 \mathrm{~K}) ; \mathrm{P} 2 \mathrm{X} 7 \mathrm{~A}$ is the full-length common $\mathrm{P} 2 \mathrm{X} 7$ subunit (Rassendren et al., 1997; Cheewatrakoolpong et al., 2005; Sluyter, 2017). Some of these variants show an altered permeability for large cations. For instance, P2X7B, a variant bearing a largely truncated C terminus, is considered "non-dilating" (Cheewatrakoolpong et al., 2005; Adinolfi et al., 2010). On the contrary, P2X7K, which features a modified TM1 sequence as well as a more lipophilic $\mathrm{N}$ terminus, has been shown to be 


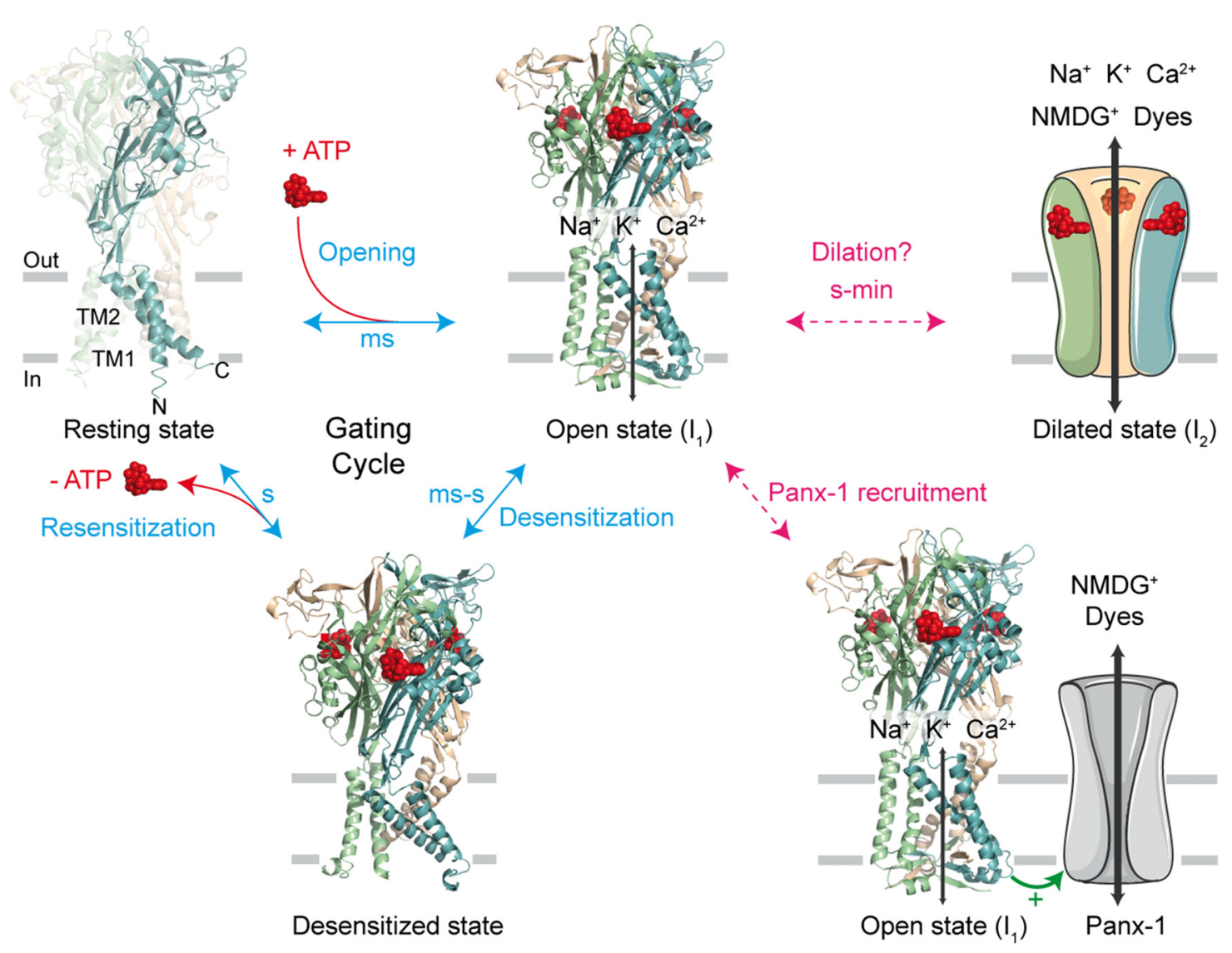

FIGURE 1 | The gating cycle and hypothetical pathways associated to permeation of large cations. In response to ATP binding, the receptor cycles between at least three functional states: the resting state, the open state (sometimes called $\mathrm{l}_{1}$ state) and the desensitized state. X-ray structures are from the human P2X3 receptor solved in the apo, resting state (PDB ID 5SVJ), ATP-bound, open channel state (5SVK) and ATP-bound, desensitized state (5SVL; Mansoor et al., 2016). Ribbon structures are viewed laterally from the membrane and each subunit is color coded (one subunit is highlighted in the resting state, in which the $\mathrm{N}$ and $\mathrm{C}$ termini are indicated). ATP is shown as a space-filling model and the lipid bilayer is symbolized by gray bars. It has been initially suggested that sustained ATP application allows the passage of large cations, such as $N$-methyl-D-glucamine (NMDG ${ }^{+}$) and fluorescent dyes, through two main putative, controversial routes. The first one involves a gradual pore dilation of the open $I_{1}$ state to reach a dilated state $\left(I_{2}\right)$; the second pathway involves the recruitment of the hemichannel pannexin-1 (Panx-1) by P2X receptor. The two models were suggested not to be mutually exclusive.

constitutively and immediately dilated (Nicke et al., 2009; Xu et al., 2012).

\section{METHODS AND INTERPRETATIONS LEADING TO THE CONTROVERTED DILATED STATE}

Two main experimental approaches have been used to monitor the apparent gradual increase in large cation permeability. In the first approach, the cellular uptake of fluorescent dyes, such as YO-PRO-1 or ethidium bromide, is observed as a function of time. Dye uptake usually develops several seconds after ATP application. As these cationic dyes become fluorescent when bound to DNA, this method is a simple and direct read-out of the passage of large molecules following P2X activation. Studies involving cysteine reactive compounds, such as methanethiosulfonate (MTS) reagents, have also shown the ability of larger sized molecules to pass into the cell (Browne et al., 2013). This method has been employed for P2X2, P2X4 and P2X7 receptors (Khakh et al., 1999; Virginio et al., 1999a,b; Yan et al., 2008).

In the second approach, the permeability of large cations is measured by patch-clamp electrophysiology (Khakh et al., 1999; Virginio et al., 1999b). In this indirect method, reversal potentials $\left(\mathrm{E}_{\text {rev }}\right)$ are measured in bi-ionic solutions, where $N$-methyl-Dglucamine $\left(\mathrm{NMDG}^{+}\right)$, a synthetic large organic cation, is the sole permeating ion present outside the cell $\left(\mathrm{NMDG}^{+}{ }_{\text {out }}\right)$ and $\mathrm{Na}^{+}$is the sole permeating cation present inside the cell $\left(\mathrm{Na}^{+}{ }_{\text {in }}\right)$. According to the Goldman-Hodgkin-Katz voltage equation, a shift in $\mathrm{E}_{\text {rev }}$ signals a change in membrane permeability to one or both cations provided the concentrations of ions on either side of the membrane remain unchanged. The gradual and positive shifts in $\mathrm{E}_{\mathrm{rev}}$ measured during long applications of ATP have been interpreted as a time-dependent change in the relative permeability of $\mathrm{NMDG}^{+}$relative to $\mathrm{Na}^{+}\left(\mathrm{P}_{\mathrm{NMDG}^{+}} / \mathrm{P}_{\mathrm{Na}^{+}}\right)$. At the 
beginning of extracellular ATP application, the agonist opens a pore that is initially more permeable to $\mathrm{Na}^{+}$than $\mathrm{NMDG}^{+}$, but during sustained activation of the channel, $\mathrm{E}_{\mathrm{rev}}$ shifts towards less negative values that signify a dramatic increase in the permeability to $\mathrm{NMDG}^{+}$(Khakh et al., 1999; Virginio et al., 1999b). This method has been extensively employed to probe shifts in $\mathrm{E}_{\text {rev }}$ for many $\mathrm{P} 2 \mathrm{X}$ receptors, such as $\mathrm{P} 2 \mathrm{X} 2, \mathrm{P} 2 \mathrm{X} 2 / 3$, P2X2/5, P2X4 and P2X7 (Khakh et al., 1999; Virginio et al., 1999a,b; Compan et al., 2012).

The fact that shifts of $\mathrm{E}_{\mathrm{rev}}$ and dye uptake occur on the same time scale has led to the belief that a common mechanism would be at work. Two main hypotheses have then emerged (Figure 1). One hypothesis involves the recruitment of an auxiliary protein by $\mathrm{P} 2 \mathrm{X}$ receptors. This protein is pannexin-1 (Panx-1), a hemichannel that is responsible for the passage of larger molecules. This hypothesis is supported by the observation that P2X permeability to large cations is inhibited when inhibitors of Panx-1 are applied (Pelegrin and Surprenant, 2006). In addition, colchicine, a drug that disrupts the cytoskeleton, has been shown to affect YO-PRO-1 uptake into cells transfected with P2X2 or P2X7 subtypes, but not the permeability for small cations. This would indicate that these two types of permeability result from different pathways (Marques-da-Silva et al., 2011).

On the other hand, a second hypothesis postulates the existence of an intrinsic "pore dilation" mechanism, whereby the P2X pore itself undergoes a slow conformational change. This would lead to a physical expansion in the diameter of the P2X ion pore from the $\mathrm{I}_{1}$ state to the putative $\mathrm{I}_{2}$ dilated state, allowing the passage of larger molecules. This "pore dilation" mechanism has been extensively studied by site-directed mutagenesis, patchclamp electrophysiology, fluorescent dye uptake and use of chemical reagents (Khakh et al., 1999; Virginio et al., 1999a,b; Eickhorst et al., 2002; Khakh and Egan, 2005; Browne et al., 2013). Moreover, it has been shown that cells which do not express Panx-1 nonetheless exhibit "dilating" properties and, in agreement with this hypothesis, overexpression or inhibition of Panx-1 by carbenoxolone does not affect dilation of P2X2 receptors expressed in HEK-293 cells (Chaumont and Khakh, 2008; Yan et al., 2008).

As evidence has been found both in support of and against each hypothetical pathway, the question has been raised as to whether these two distinct mechanisms may in fact co-exist (Jiang et al., 2005; Cankurtaran-Sayar et al., 2009). One mechanism would be dedicated to $\mathrm{NMDG}^{+}$permeability and the other to larger molecules such as YO-PRO-1 and even occasionally the permeation of organic anions (Browne et al., 2013). Moreover, interactions with other proteins may play a role. For instance, cytoskeletal proteins have been described as important for pore dilation in P2X7 receptor subtype (Kim et al., 2001; Gu et al., 2009). In addition, characterization of the apparent "pore dilation" has been shown to be dependent on cell types used for experiments as well as expression levels of receptors (Fujiwara and Kubo, 2004). Of greatest importance is the fact that dynamic changes of unitary conductance following prolonged ATP application have never been observed at the single channel level (Ding and Sachs, 1999; Riedel et al., 2007b), thus bringing into question the reality of an intrinsic "pore dilation".

\section{CHANGING THE PARADIGM}

In 2015, the team of K. Swartz offered an alternative explanation of the change in $\mathrm{E}_{\mathrm{rev}}$ measured in bi-ionic $\mathrm{NMDG}_{\mathrm{out}}^{+} / \mathrm{Na}_{\text {in }}^{+}$ solutions ( $\mathrm{Li}$ et al., 2015). The authors elegantly demonstrate in the P2X2 receptor that shifts in $\mathrm{E}_{\mathrm{rev}}$, although very real, are not caused by a time-dependent change in channel permeability, but rather by a dramatic and unappreciated change of the intracellular ion concentrations, which may vary by more than $100 \mathrm{mM}$ throughout the course of the experiment. Combining electrophysiology and mathematical modeling, the authors were able to convincingly demonstrate that prolonged ATP activation leads to a depletion of intracellular $\mathrm{Na}^{+}$, from $140 \mathrm{mM}$ to around $20 \mathrm{mM}$, and accumulation of $\mathrm{NMDG}^{+}$, from $0 \mathrm{mM}$ to over $200 \mathrm{mM}$. They further showed that physical parameters such as channel densities, pore conductance, cell volume, and access resistance ( $R_{\text {access }}$ ) between the cell and the pipette electrode, may directly change ion concentrations inside the cell following sustained exposure to ATP. Because of these changes, the Goldman-Hodgkin-Katz voltage equation cannot be used to reliably determine the relative permeability of ions. This study therefore proved that the time-dependent shift in the $\mathrm{E}_{\mathrm{rev}}$ measured in bi-ionic solutions is an artifact of the method employed, and that extreme caution must be taken when measuring permeability changes during whole-cell patch-clamp recordings.

This outstanding article seriously challenges the pore dilation paradigm which held true for almost two decades. However, it is important to emphasize that the study did not question the ability of $\mathrm{NMDG}^{+}$to permeate through the activated P2X pore, as initially suggested by the seminal articles (Khakh et al., 1999; Virginio et al., 1999b), but that this $\mathrm{NMDG}^{+}$ permeation occurs soon after ATP activation. As a direct proof of this assumption, Li et al. (2015) showed that whole-cell currents carried by $\mathrm{NMDG}^{+}$using symmetrical solutions (whereby both intracellular and extracellular solutions contain $\mathrm{NMDG}^{+}$) developed immediately following ATP application. These observations indicate that a gradual pore dilation mechanism is not necessary to account for $\mathrm{NMDG}^{+}$ permeation.

\section{A NEW MECHANISTIC POINT OF VIEW}

The publication of $\mathrm{Li}$ et al. (2015) opens an appealing hypothesis: the dimensions of the pore itself may be directly adequate for the direct passage of $\mathrm{NMDG}^{+}$following several milliseconds of ATP application. From a mechanistic point of view, the $I_{1}$ state would represent the most parsimonious hypothesis, provided the diameter of the narrowest part of its open pore is sufficiently wide to allow the passage of such large molecules. We have investigated this possibility by combining single-channel recordings, molecular modeling and 
the use of photo-switchable tweezers (Harkat et al., 2017), a recently developed technology that allows identification of the molecular motions involved in channel activation (Habermacher et al., 2016b). By covalently tethering synthetic azobenzene cross-linkers to a pair of selected engineered cysteine residues, these "molecular tweezers" are capable of pulling or pushing on gating elements once azobenzene isomerization is triggered by light irradiation. To provide a read-out of the large cation permeation, we used symmetric $\mathrm{NMDG}^{+}$solutions, where $\mathrm{NMDG}^{+}$was the sole permeating ion. A rapid solution exchange of the extracellular solutions from an $\mathrm{NMDG}^{+}$-containing to a $\mathrm{Na}^{+}$-containing solution allowed direct comparison of molecular motions involved in pore opening and permeation of $\mathrm{NMDG}^{+}$and $\mathrm{Na}^{+}$. We screened several positions near a flexible region of TM2 in the $\mathrm{P} 2 \mathrm{X} 2$ receptor, as well as a region of the pore surrounding a kink that was previously identified in channel gating (Habermacher et al., 2016b; Mansoor et al., 2016). Firstly, we identified two types of molecular motions involved in the permeation of large cations: a horizontal expansion of the upper end of TM2 helices and a vertical flexing of the extremities of two adjacent TM2 helices. Surprisingly, we observed no $\mathrm{NMDG}^{+}$permeation for mutants bearing no permeability to $\mathrm{Na}^{+}$, suggesting that none of the molecular motions that we monitored can produce a pathway dedicated exclusively to $\mathrm{NMDG}^{+}$permeation. Secondly, for the motions that allowed the passage of both $\mathrm{NMDG}^{+}$ and $\mathrm{Na}^{+}$, the ratio of the current $\mathrm{I}_{\mathrm{NMDG}^{+}} / \mathrm{I}_{\mathrm{Na}^{+}}$was around $10 \%$, suggesting that $\mathrm{NMDG}^{+}$follows the same pathway as $\mathrm{Na}^{+}$across the P2X pore but is not able to permeate as easily.

To further support this observation, we recorded ATP-induced single-channel currents from outside-out patches using symmetrical $\mathrm{NMDG}^{+}$solutions (Figure $2 \mathrm{~A}$ ). We not only showed that $\mathrm{P} 2 \mathrm{X} 2$ receptors are $\mathrm{NMDG}^{+}$-permeable channels, activated on the millisecond timescale, with kinetics similar to those observed when $\mathrm{Na}^{+}$is the primary permeating ion, but we also established the first measurements of the unitary conductance of $\mathrm{NMDG}^{+}$currents (around four $\mathrm{pS}$ for several ATP concentrations). This is approximately 10 times lower than that of $\mathrm{Na}^{+}$currents. We further confirmed these experimental data by molecular dynamic simulations carried out on a model of ATP-bound P2X receptors. These computations represent a step forwards in the understanding of the molecular mechanism of $\mathrm{NMDG}^{+}$permeation, which is the result of a conformational and orientational selection process (Harkat et al., 2017). We further validated our methodology by measuring YO-PRO-1 uptake in cells expressing engineered receptors, to discount the presence of possible artifacts caused by the use of non-physiological media for electrophysiological recordings. For the mutants exhibiting light-induced motions leading to a "desensitizinglike" phenotype, we were not able to show fluorescence uptake, but for those associated with a stable opening induced by light, YO-PRO-1 was successfully incorporated into cells, suggesting that desensitization may hinder dye accumulation into cells. However, no YO-PRO-1 uptake was observed during molecular dynamic simulations, which brings back the possibility of two distinct mechanisms for YO-PRO-1 and $\mathrm{NMDG}^{+}$uptake.
Alternatively, this could be the result of a limitation of the method used, as it is possible that the sampling time for computations may not have been sufficient to observe the passage of low-conductance YO-PRO-1. Altogether, our data support that the open $\mathrm{I}_{1}$ state likely represents the main route for both small and large cations (Figure 2B).

In agreement with data obtained from P2X2 receptors, two recent reports carried out on $\mathrm{P} 2 \mathrm{X} 7$ receptors further support an instantaneous permeation of large cations upon ATP activation (Karasawa et al., 2017; Pippel et al., 2017). In the first study, a rigorous and thorough analysis of single-channel currents demonstrate that the unitary conductance of the human P2X7 channel remains stable over time following prolonged ATP application (up to $30 \mathrm{~min}$; Riedel et al., 2007a,b; Pippel et al., 2017). Interestingly, the authors even showed that chemical modification of engineered cysteine side chains with charged MTS reagents increased dramatically the open probability of the channel, with no sign of apparent pore dilation (Pippel et al., 2017). In the second study, the biophysical properties of the "macropore" feature of P2X7 channel have been scrutinized in a synthetic system, in which the functionality of the P2X7 protein has been monitored in the absence of other protein cellular components (Karasawa et al., 2017). To do so, a purified, yet truncated, version of the giant panda $\mathrm{P} 2 \mathrm{X} 7$ receptor (pdP2X7- $\triangle \mathrm{NC}$ ) was reconstituted into manufactured liposomes. To distinguish channel activity ( $\mathrm{I}_{1}$ state) from "macropore" formation $\left(\mathrm{I}_{2}\right.$ state), proteoliposomes encapsulated either Fluo4 , a $\mathrm{Ca}^{2+}$-sensing fluorescent probe, or DNA, to which binding of YO-PRO-1 enhances dye fluorescence emission. The authors elegantly and convincingly showed that pdP2X7- $\triangle \mathrm{NC}$ was not only permeable to YO-PRO-1, but also to $\mathrm{Ca}^{2+}$ with the same apparent kinetics, suggesting a common pathway for both small and large cations (Karasawa et al., 2017). Therefore, in a reconstituted system, the purified $\mathrm{P} 2 \mathrm{X} 7$ receptor is able to form an intrinsic and immediate dye-permeable pore with no apparent time-lag, a finding that is apparently not compatible with the slow and progressive process of pore dilation.

\section{IS THE CONCEPT OF PORE DILATION DEAD?}

As stated above, recent data now support the hypothesis that the open $\mathrm{I}_{1}$ state would be sufficiently wide to allow the passage of relatively large molecules, without the need for an ATP-induced pore dilation. However, comparison of the structure of the largest permeating molecules with recent X-ray structures of the ATP-bound, open state casts doubt on the fact that the open $I_{1}$ state truly represents the sole ion pathway (Figure 3 ). This is particularly true for P2X7 receptors, for which MTSrhodamine, a nanometer-sized dye, was shown to penetrate the open channel and block at a cysteine-substituted residue located deeply in the pore (Browne et al., 2013), whereas the structure of the open pore derived from the human $\mathrm{P} 2 \mathrm{X} 3$ receptor (the structure of $\mathrm{P} 2 \mathrm{X} 7$ open pore is not yet determined) appears to be too narrow to accommodate such a molecule. Interestingly, molecules of similar size, such as Texas Red-MTSEA, cannot 

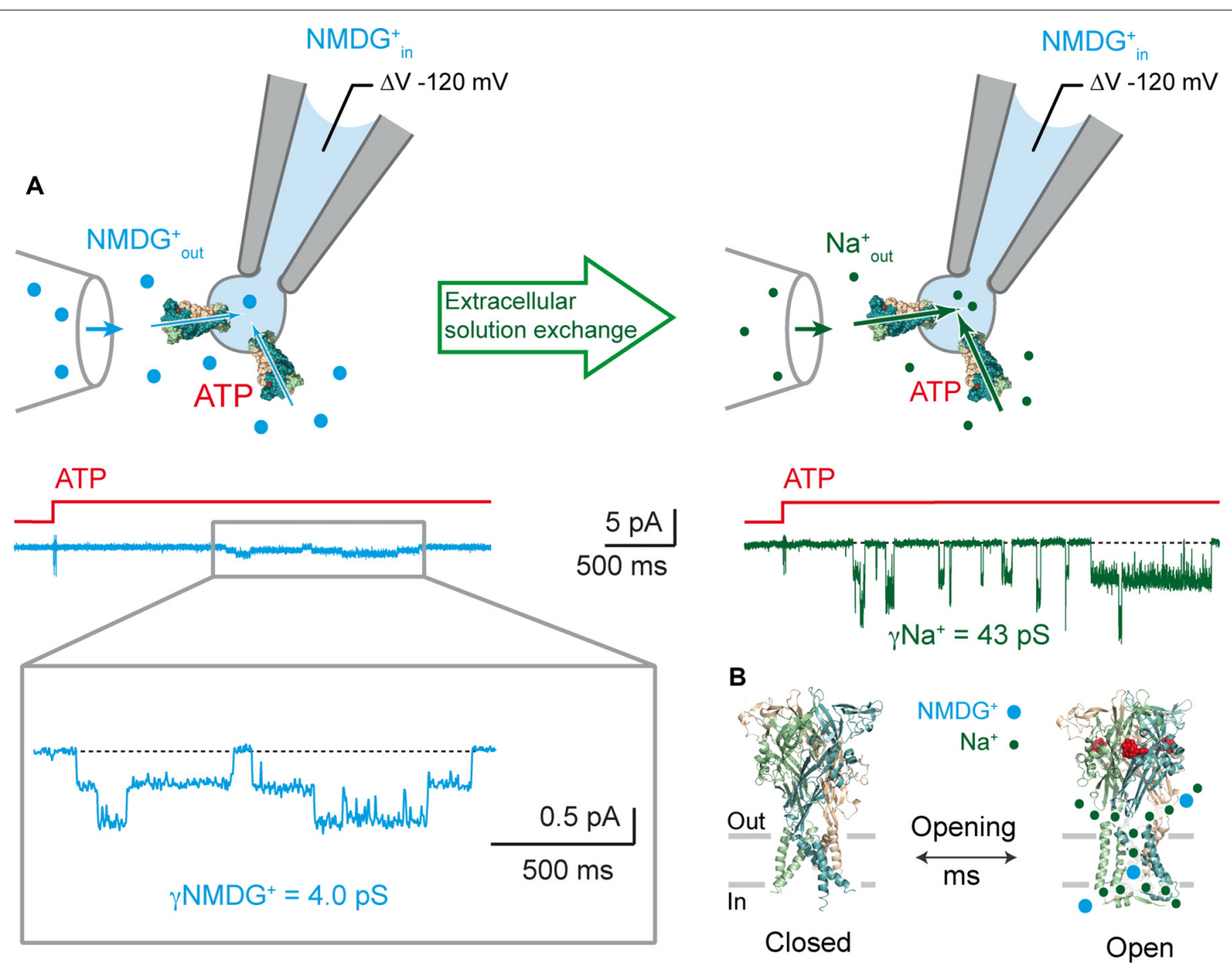

C

$\mathrm{hP} 2 \mathrm{X} 2$

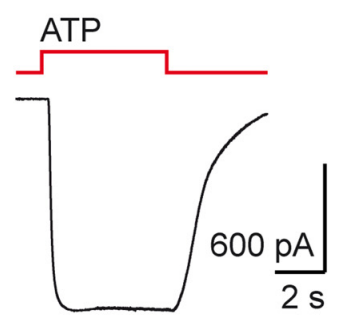

hP2X3

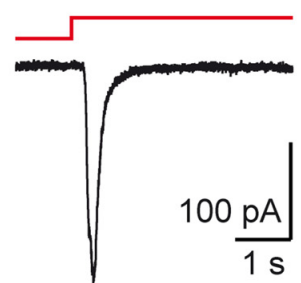

rP2X4

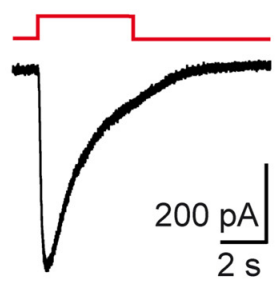

$\mathrm{rP} 2 \mathrm{X} 7$

FIGURE 2 | P2X receptors are rapidly permeable to large cations. (A) Rapid onset of single-channel NMDG ${ }^{+}$currents following ATP application. Top: schematic drawing of the outside-out configuration and perfusion glass tube. Note that patch pipette contains NMDG ${ }^{+}$. Bottom: Single-channel currents elicited by $1 \mu \mathrm{M}$ ATP from an outside-out patch expressing the rat P2X2 receptor. Currents were first recorded in extracellular $\mathrm{NMDG}^{+}$out solution (symmetric $\mathrm{NMDG}^{+}$out $/ \mathrm{NMDG}^{+}{ }_{\text {in }}$, left, blue), and then in extracellular $\mathrm{Na}^{+}{ }_{\text {out }}$ solution $\left(\mathrm{Na}^{+}{ }_{\text {out }} / \mathrm{NMDG}^{+}{ }_{\text {in }}\right.$, right, green), following rapid solution exchange. Currents were recorded at $-120 \mathrm{mV}$ and filtered at $1 \mathrm{kHz}$. Inset shows magnification of $\mathrm{NMDG}^{+}$currents filtered at $100 \mathrm{~Hz}$. ATP applications are indicated by red stepped bars. Adapted from Harkat et al. (2017). (B) Proposed model in which $\mathrm{NMDG}^{+}$and $\mathrm{Na}^{+}$ions transit through the same open pore at different flow rates following rapid $\mathrm{ATP}$ activation $\left(\sim 2.5 \times 10^{6} \mathrm{NMDG}^{+}\right.$ ions/s at $-120 \mathrm{mV}$ with $132.6 \mathrm{mM} \mathrm{NMDG}^{+}, 32 \times 10^{6} \mathrm{Na}^{+}$ions/s at $-120 \mathrm{mV}$ with $132.6 \mathrm{mM} \mathrm{Na}^{+}$; data taken from Harkat et al. (2017)). (C) Whole-cell ATP-gated currents recorded in symmetric spermidine solution at $-60 \mathrm{mV}$ from HEK-293 cells expressing the indicated P2X receptors. Traces for $\mathrm{hP} 2 \mathrm{X} 2 \mathrm{and} \mathrm{hP} 2 \mathrm{X} 3$ are adapted from Harkat et al. (2017). ATP concentration was $30 \mu \mathrm{M}$ for hP2X2 and hP2X3, $100 \mu \mathrm{M}$ for rP2X4, and $1000 \mu \mathrm{M}$ for rP2X7.

enter the P2X2 pore (Li et al., 2015) suggesting that the $\mathrm{P} 2 \mathrm{X} 7$ receptor, when activated by ATP, can reach a diameter that is larger than that of the P2X2 receptor (Figure 3). Other routes specifically dedicated to the permeation of such very large molecules may also exist. As stated above, Panx-1 is a candidate, as close proximity between Panx-1 and P2X7 channels has been established in human and mouse macrophages cells (Pelegrin and Surprenant, 2006). Alternatively, there is still a possibility that P2X7 receptors do indeed dilate under certain conditions that remain to be determined.

A finding which may reconcile P2X7 (and perhaps other P2X subtypes) with the concept of "pore dilation" comes from recent studies that emphasize the importance of the lipid composition of the membrane for the passage of large cations through the P2X pore. Although lipids, such as phosphoinositides (Bernier et al., 2008a,b) and cholesterol (Murrell-Lagnado, 2017), 


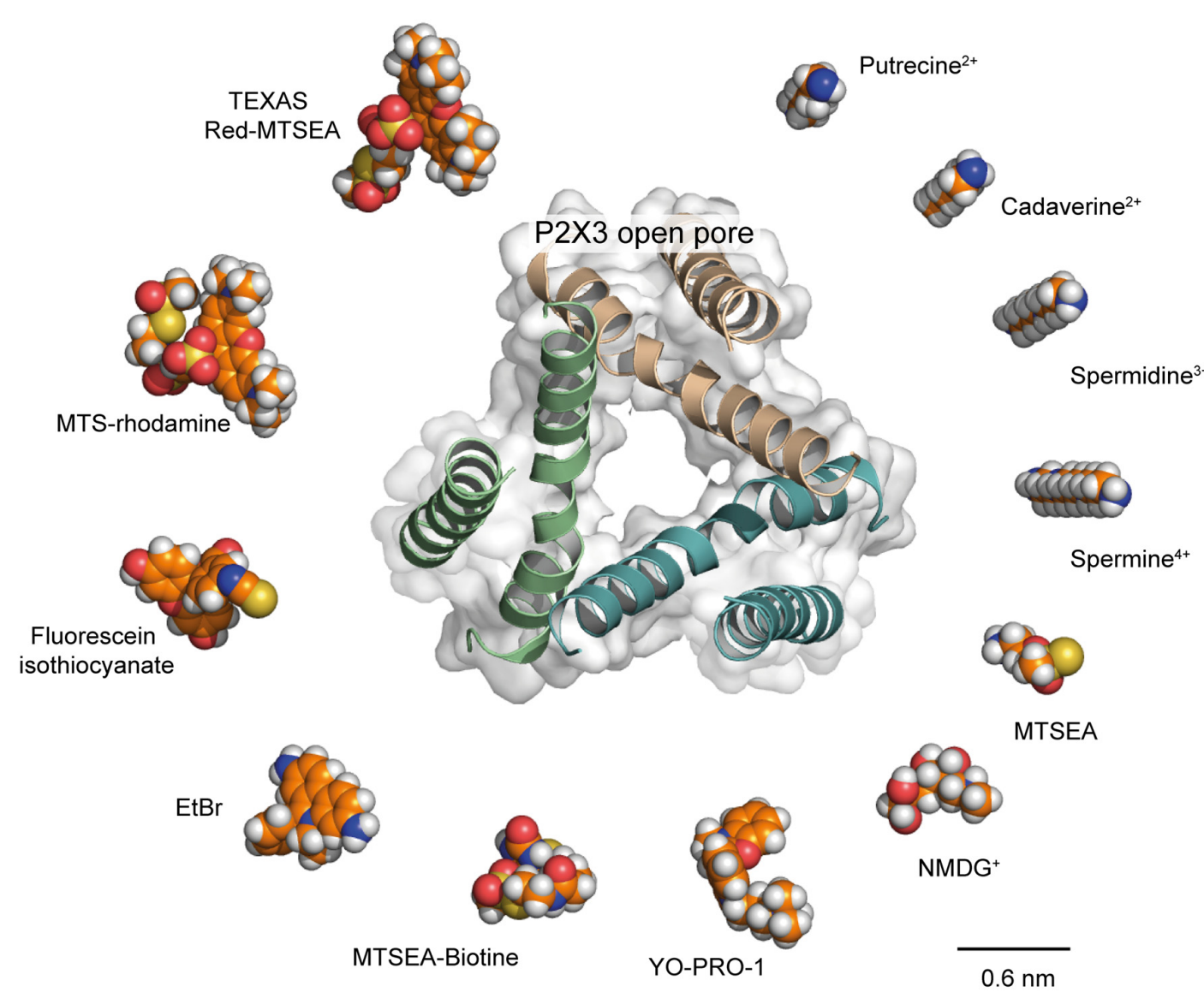

FIGURE 3 | Is the P2X open pore sufficiently wide to allow the passage of large molecules? Comparison of structures of selected organic molecules, shown as space-filling models, scaled to the X-ray structure of the P2X3 open pore (PDB ID: 5SVK), viewed along the three-fold axis of symmetry. Receptor ribbon structure is superimposed to the protein surface. Shown is a clockwise ranking of molecules, from the smallest (putrescine, top right) to the largest dimensions (Texas Red-MTSEA, top left). Valency of cations is also indicated. Recent evidence supporting permeation of NMDG ${ }^{+}$and spermidine through the P2X2 open $I_{1}$ state (Harkat et al., 2017) suggests that molecules of similar size to these cations should also permeate the P2X open pore. For slightly larger molecules, such as YO-PRO-1, for which their dimensions reach those of the open pore, we propose that such molecules follow the same pathway as Na ${ }^{+}$across the P2X pore but are not able to permeate as easily. For the largest molecules, such as Texas Red-MTSEA, there is evidence that they cannot enter the P2X2 pore (Li et al., 2010). However, methanethiosulfonate (MTS)-rhodamine, which has a size that is similar to that of Texas Red-MTSEA, has been shown to directly permeate the P2X7 pore (Browne et al., 2013), suggesting the P2X7 open pore is larger than that of P2X2. From a structural point of view, the open state of the P2X3 receptor seems too narrow to allow the passage of MTS-rhodamine. Therefore, either the structure of P2X7 open state is different from that of the P2X3 receptor or other routes specifically dedicated to the permeation of such very large molecules in P2X7 receptors exist. Carbon atoms are indicated in orange; nitrogen atoms in blue, oxygen atoms in red; phosphorus atoms in yellow, and hydrogen atoms in white.

seem to be important for the regulation of allosteric states of $\mathrm{P} 2 \mathrm{X}$ receptors, this factor has been underestimated in "dilation" studies thus far. However, Kawate and co-workers (Karasawa et al., 2017) have very recently demonstrated in reconstituted liposomes that sphingomyelin and phosphatidylglycerolcontaining membranes facilitate pdP2X7- $\Delta$ NC-dependent dye uptake, whereas the presence of cholesterol rather inhibits this process. It is thus conceivable that the lipid composition may have a direct impact on the physical diameter of the P2X7 open channel state that would allow the passage of very large molecules (up to $900 \mathrm{Da}$ ). Alternatively, a conformational plasticity in the selectivity filter of the P2X pore may allow the passage of large molecules, as very recently shown on TRPV2 ion channel (Zubcevic et al., 2018). Although appealing, these hypotheses need convincing evidence; in particular the structure of the P2X7 open channel state (and also other P2X subtypes) solved in a lipid bilayer will certainly advance this issue.

\section{PHYSIOPATHOLOGICAL ROLE OF LARGE CATION PERMEATION}

Now that there is no doubt that $\mathrm{P} 2 \mathrm{X}$ receptors are permeable to large cations, is there any link between this feature and pathological states? Evidence exists indicating a possible link at least involving the P2X7 receptor, which is arguably of most therapeutic interest due to its implication in a large variety of diseases. Expressed in a range of immune and microglial 
TABLE 1 | Polyamine modulation of ion channels and ligand-gated ion channels.

\begin{tabular}{|c|c|c|}
\hline $\begin{array}{l}\text { Ion channel/ligand-gated ion } \\
\text { channel }\end{array}$ & Nature of the interaction with polyamines & $\begin{array}{l}\text { Observations suggesting a possible } \\
\text { implication of P2X receptors }\end{array}$ \\
\hline AMPA receptors & $\begin{array}{l}\text { Voltage-dependent block by intracellular polyamines } \\
\text { (Bowie et al., 1998) }\end{array}$ & $\begin{array}{l}\text { Co-localization } \\
\text { Synaptic scaling } \\
\text { Synaptic depression } \\
\text { Functional interactions } \\
\text { (Pougnet et al., 2014) }\end{array}$ \\
\hline Kainate receptors & $\begin{array}{l}\text { Voltage-dependent block by intracellular polyamines } \\
\text { (Perrais et al., 2010) }\end{array}$ & $\begin{array}{l}\text { Co-expression of kainate receptors and } \\
\text { P2X receptors in some populations of neurons } \\
\text { (Lucifora et al., 2006) }\end{array}$ \\
\hline NMDA receptors & $\begin{array}{l}\text { Potentiation by extracellular polyamines, existence of a } \\
\text { polyamine binding site } \\
\text { (Han et al., 2008; Mony et al., 2011) }\end{array}$ & $\begin{array}{l}\text { Modulation of NMDA-dependent plasticity } \\
\text { (Boué-Grabot and Pankratov, 2017) }\end{array}$ \\
\hline Nicotinic receptors & $\begin{array}{l}\text { Binding site for polyamine-derived toxins } \\
\text { (Bixel et al., 2001) }\end{array}$ & $\begin{array}{l}\text { Interaction between nicotinic receptors } \\
\text { and P2X receptors: cross inhibition } \\
\text { (Khakh et al., 2005) }\end{array}$ \\
\hline Inward rectifier $\mathrm{K}^{+}$(Kir) channels & $\begin{array}{l}\text { Voltage-dependent blockage by intracellular polyamines } \\
\text { Existence of a polyamine binding site } \\
\text { (Kurata et al., 2006) }\end{array}$ & To be determined \\
\hline ASICs & $\begin{array}{l}\text { Potentiation by spermine } \\
\text { (Babini et al., 2002) }\end{array}$ & $\begin{array}{l}\text { Functional interaction between P2X receptors and ASICs } \\
\text { (Birdsong et al., 2010; Stephan et al., 2018) }\end{array}$ \\
\hline TRPV1 receptors & $\begin{array}{l}\text { Polyamines can act as ligands and are } \\
\text { able to pass through TRPV1 } \\
\text { (Ahern et al., 2006) }\end{array}$ & $\begin{array}{l}\text { Cross-talk between TRPV1 and P2X receptors } \\
\text { (Stanchev et al., 2009) }\end{array}$ \\
\hline
\end{tabular}

cells, P2X7 receptors are widely involved in the immune and inflammatory response, notably in the nervous system. Several recent reviews extensively cover the involvement of $\mathrm{P} 2 \mathrm{X} 7$ receptors in pathological immune-related conditions, such as neuropathic pain, Alzheimer's disease, Huntington's disease and multiple sclerosis to name but a few (De Marchi et al., 2016; Di Virgilio et al., 2017; Savio et al., 2018). A first possible link may involve the ability of Panx-1 channels to allow entry of large cations into the cell, as it has been demonstrated that an increase in extracellular ATP induces the clustering of Panx-1 with P2X7 receptors, leading to their internalization (Boyce et al., 2015). An impairment of this internalization mechanism could contribute to the over-activity of P2X-mediated signaling that may lead to pathophysiological states, such as neuropathic pain (Swayne and Boyce, 2017). Another possible link may involve the P2X7 protein itself. An association between nerve-induced pain behavior (mechanical allodynia) and the P451L mutation found in the mouse $P 2 r x 7$ gene has been identified. This mutation impaired "pore formation" by affecting the entry of YO-PRO1 and ethidium bromide in HEK-293 cells and calcein dye into macrophages, but interestingly the mutation did not affect $\mathrm{Ca}^{2+}$ entry (Adriouch et al., 2002; Young et al., 2006; Sorge et al., 2012). Mice in which $\mathrm{P} 2 \mathrm{X} 7$ receptors have impaired pore formation as a result of this mutation showed less allodynia than mice with the pore-forming receptors. Moreover, in two independent human chronic pain cohorts, it has been shown that human mutations affecting the amino acid sequence of P2X7 receptor modify the chronic pain sensitivity (Sorge et al., 2012). For instance, in the cohort experiencing post-mastectomy chronic pain, the H155Y single nucleotide polymorphism, which leads to hyperfunctional P2X7 receptors, was associated with an increased pain sensitivity. In contrast, mastectomized women with the hypofunctional mutation $\mathrm{R} 270 \mathrm{H}$ of $\mathrm{P} 2 \mathrm{X} 7$ receptor, experienced reduced chronic pain (Sorge et al., 2012). These correlations thus clearly suggest that the level of pore activity is related to pathological states and indicate that $\mathrm{P} 2 \mathrm{X} 7$ receptors are vital targets for the treatment of diseases such as neuropathic pain. Differences in $\mathrm{Na}^{+}, \mathrm{K}^{+}$ and $\mathrm{Ca}^{2+}$ ion flux may trigger such pathological responses, but permeation of large, pathologically relevant cations may also be involved. These large molecules remain to be identified.

\section{NEW DIRECTIONS CONCERNING THE P2X PERMEATION OF LARGE CATIONS: THE CASE OF POLYAMINES}

What is the physiological implication of P2X permeability to large cations? To answer to this question, it is first important to consider whether this unusual large cation permeation feature is shared by all members of the P2X family. Before 2017, a striking observation was that fast-desensitizing receptors, namely $\mathrm{P} 2 \mathrm{X} 1$ and $\mathrm{P} 2 \mathrm{X} 3$ receptors, were apparently unable to allow the entry of larger cations through the pore. By using symmetric solutions, we have provided evidence that P2X3 receptors are actually permeable to $\mathrm{NMDG}^{+}$, suggesting that these receptors should be reconsidered as channels permeable to large cations (Harkat et al., 2017). However, $\mathrm{NMDG}^{+}$is a synthetic molecule, and we sought rather to establish the permeability of large, naturally occurring cations through the $\mathrm{P} 2 \mathrm{X}$ pore. We have very recently found that spermidine permeates through the human P2X2 and P2X3 receptor ion channels (Harkat et al., 2017). Now we have extended this permeation to the rat $\mathrm{P} 2 \mathrm{X} 4$ and $\mathrm{P} 2 \mathrm{X} 7$ receptors, suggesting permeation of spermidine may be a common feature 
shared by many, if not all members of the P2X family (Figure 2C).

Spermidine is a natural, ubiquitously distributed polyamine that is vital for the cell (Guerra et al., 2016; Madeo et al., 2018). It is formed intracellularly and is involved in several important cellular functions, such as growth, division and proliferation. Spermidine is also recognized as an allosteric modulator of many ion channels, including ionotropic glutamate receptors, nicotinic acetylcholine receptor, potassium channels, ASICs and TRPV1 channels (Table 1). For some of these channels, spermidine must exit the cell through dedicated pathways to reach the targeted extracellular sites. One of these such pathways may be the vesicular polyamine transporter (VPAT) that stores polyamines in secretory vesicles in astrocytes and mast cells (Hiasa et al., 2014; Takeuchi et al., 2017). As we provide evidence that spermidine permeates through the open pore of $\mathrm{P} 2 \mathrm{X}$ receptors (Figure $2 \mathrm{C}$ ), we propose that $\mathrm{P} 2 \mathrm{X}$ receptors may represent an alternative polyamine pathway that is under the control of ATP. Given the importance of spermidine for the function of several other ion channels, as well as the known interactions of P2X receptors with such channels (Khakh et al., 2005; Stanchev et al., 2009; Pougnet et al., 2014; Boué-Grabot and Pankratov, 2017; Stephan et al., 2018), the question is now raised as to what extent can $\mathrm{P} 2 \mathrm{X}$ receptors be the physiological mediator of spermidine transit.

By discovering spermidine permeation through P2X receptors, our results uncover a possible overlooked P2X signaling pathway that may be extended to other natural large molecules. Earlier work provided strong evidence that P2X7 receptors are sites of release of important molecules, such as ATP and excitatory amino acids (Duan et al., 2003; Pellegatti et al., 2005; Suadicani et al., 2006; Di Virgilio et al., 2018). It now remains to determine whether these signaling molecules are physically able to cross directly through the P2X7 open pore. Identification of the mechanisms involved will undoubtedly advance the biology of $\mathrm{P} 2 \mathrm{X}$ receptors and their role in pathological states.

\section{COULD P2X RECEPTORS ACT AS A PATHWAY FOR THERAPEUTIC APPLICATIONS?}

P2X receptors can act as a pathway for the entry of large molecules into cells-to what extent can this property be exploited for therapeutic applications? Two examples of P2X receptors being used as pathways for the passage of azobenzenebased molecules have been published by the team of R. Kramer. The first example is related to the control of nociception, by manipulation of neurons involved in pain signaling via voltage-gated ion channels (Mourot et al., 2012). This was carried out by the incorporation of QAQ, an azobenzene-based photoswitch bearing two quaternary ammonium moieties, into cells through the P2X pore. Control of nociception is based on the activation/deactivation process of local voltage-gated ion channels (calcium, potassium, sodium), which is provided by the geometrical switching between trans and cis isomers of
QAQ. The route responsible for the entry of QAQ, which is otherwise a membrane-impermeable molecule, can be TRPV1 or alternatively P2X7 receptors (Mourot et al., 2012). In 2016, they further developed this concept of P2X-mediated membrane passage in order to resurrect light-sensitivity of retinal ganglion cells of degenerated retina in blind mice. They employed the same methodology: a charged photoswitchable molecule based on an azobenzene moiety is applied to cells and permeates the membrane via P2X receptors. This molecule is then able to act on voltage-gated ion channels, restoring the responsiveness of retinal-ganglion cells to light (Tochitsky et al., 2016).

As stated above, the presence and implication of P2X7 in many diseases could inspire new approaches, whereby the permeability of the receptor to large cations may be utilized to therapeutic effect, in the delivery of biological effectors to P2X7-expressing cells. Equally, P2X7 has been found in over-expressed levels in several types of cancers, such as chronic B lymphocytic leukemia (De Marchi et al., 2016) and thyroid papillary cancer (Solini et al., 2008). One could envisage the exploitation of these high expression levels in conjunction with the permeability of P2X7 to large molecules, to deliver anti-cancer drugs through the $\mathrm{P} 2 \mathrm{X} 7$ pathway.

\section{CONCLUSION}

For some time now, there has been much controversy surrounding the passage of large cations through the P2X pore, and a clear explanation on the mechanism of this particular permeation pathway has remained highly elusive. However, recent advances in experimental technique allow a more just study of large cation permeation. Equally, new information showing the highly sensitive nature of P2X7 function to lipid membrane composition, which can vary between cellular types, may be considered in future studies probing the permeability of P2X7 to large cations.

New important features of $\mathrm{P} 2 \mathrm{X}$ receptor permeability are now being brought to light. First, it is important to reconsider the structure of the open state, which exhibits an immediate extended permeability, and to consider more closely the critical role of the membrane lipid environment in order to fully understand the functionality of these proteins. Secondly, their physiological importance must also be reconsidered, with the new information that they are able to allow the passage of important physiological modulators. A final interesting point is to look further into the potential application of $\mathrm{P} 2 \mathrm{X}$ receptors as pathway for drug delivery.

\section{AUTHOR CONTRIBUTIONS}

LP, KD, TC and TG wrote the manuscript. JB made the figures.

\section{FUNDING}

This work was supported by the Agence Nationale de la Recherche (grant no. ANR-14-CE11-0004-01) and the Ministère de la Recherche. 


\section{REFERENCES}

Abbracchio, M. P., and Burnstock, G. (1994). Purinoceptors: are there families of P2X and P2Y purinoceptors? Pharmacol. Ther. 64, 445-475. doi: 10.1016/01637258(94)00048-4

Abbracchio, M. P., Burnstock, G., Verkhratsky, A., and Zimmermann, H. (2009). Purinergic signalling in the nervous system: an overview. Trends Neurosci. 32, 19-29. doi: 10.1016/j.tins.2008.10.001

Adinolfi, E., Cirillo, M., Woltersdorf, R., Falzoni, S., Chiozzi, P., Pellegatti, P., et al. (2010). Trophic activity of a naturally occurring truncated isoform of the P2X7 receptor. FASEB J. 24, 3393-3404. doi: 10.1096/fj.09-153601

Adriouch, S., Dox, C., Welge, V., Seman, M., Koch-Nolte, F., and Haag, F. (2002). Cutting edge: a natural P451L mutation in the cytoplasmic domain impairs the function of the mouse P2X7 receptor. J. Immunol. 169, 4108-4112. doi: 10.4049/jimmunol.169.8.4108

Ahern, G. P., Wang, X., and Miyares, R. L. (2006). Polyamines are potent ligands for the capsaicin receptor TRPV1. J. Biol. Chem. 281, 8991-8995. doi: 10.1074/jbc.M513429200

Babini, E., Paukert, M., Geisler, H.-S., and Grunder, S. (2002). Alternative splicing and interaction with di- and polyvalent cations control the dynamic range of acid-sensing ion channel 1 (ASIC1). J. Biol. Chem. 277, 41597-41603. doi: 10.1074/jbc.m205877200

Banke, T. G., Chaplan, S. R., and Wickenden, A. D. (2010). Dynamic changes in the TRPA1 selectivity filter lead to progressive but reversible pore dilation. Am. J. Physiol. Cell Physiol. 298, C1457-C1468. doi: 10.1152/ajpcell.00489.2009

Bernier, L.-P., Ase, A. R., Chevallier, S., Blais, D., Zhao, Q., Boué-Grabot, E., et al. (2008a). Phosphoinositides regulate P2X $\mathrm{X}_{4}$ ATP-gated channels through direct interactions. J. Neurosci. 28, 12938-12945. doi: 10.1523/JNEUROSCI.3038-08. 2008

Bernier, L.-P., Ase, A. R., Tong, X., Hamel, E., Blais, D., Zhao, Q., et al. (2008b). Direct modulation of $\mathrm{P}_{2} \mathrm{X}_{1}$ receptor-channels by the lipid phosphatidylinositol 4,5-bisphosphate. Mol. Pharmacol. 74, 785-792. doi: 10.1124/mol.108.047019

Bernier, L.-P., Ase, A. R., and Séguéla, P. (2017). P2X receptor channels in chronic pain pathways. Br. J. Pharmacol. 175, 2219-2230. doi: 10.1111/bph.13957

Birdsong, W. T., Fierro, L., Williams, F. G., Spelta, V., Naves, L. A., Knowles, M., et al. (2010). Sensing muscle ischemia: coincident detection of acid and ATP via interplay of two ion channels. Neuron 68, 739-749. doi: 10.1016/j.neuron. 2010.09.029

Bixel, M. G., Weise, C., Bolognesi, M. L., Rosini, M., Brierly, M. J., Mellor, I. R., et al. (2001). Location of the polyamine binding site in the vestibule of the nicotinic acetylcholine receptor ion channel. J. Biol. Chem. 276, 6151-6160. doi: 10.1074/jbc.M008467200

Boué-Grabot, E., and Pankratov, Y. (2017). Modulation of central synapses by astrocyte-released ATP and postsynaptic P2X receptors. Neural Plast. 2017:9454275. doi: 10.1155/2017/9454275

Bowie, D., Lange, G. D., and Mayer, M. L. (1998). Activity-dependent modulation of glutamate receptors by polyamines. J. Neurosci. 18, 8175-8185. doi: 10.1523/JNEUROSCI.18-20-08175.1998

Boyce, A. K. J., Kim, M. S., Wicki-Stordeur, L. E., and Swayne, L. A. (2015). ATP stimulates pannexin 1 internalization to endosomal compartments. Biochem. J. 470, 319-330. doi: 10.1042/bj20141551

Brake, A. J., Wagenbach, M. J., and Julius, D. (1994). New structural motif for ligand-gated ion channels defined by an ionotropic ATP receptor. Nature 371, 519-523. doi: 10.1038/371519a0

Browne, L. E., Compan, V., Bragg, L., and North, R. A. (2013). P2X7 receptor channels allow direct permeation of nanometer-sized dyes. J. Neurosci. 33, 3557-3566. doi: 10.1523/JNEUROSCI.2235-12.2013

Burnstock, G. (1990). Overview. Purinergic mechanisms. Ann. N Y Acad. Sci. 603, 1-17; discussion 18. doi: 10.1111/j.1749-6632.1990.tb37657.x

Cankurtaran-Sayar, S., Sayar, K., and Ugur, M. (2009). P2X7 receptor activates multiple selective dye-permeation pathways in RAW 264.7 and human embryonic kidney 293 cells. Mol. Pharmacol. 76, 1323-1332. doi: 10.1124/mol. 109.059923

Chataigneau, T., Lemoine, D., and Grutter, T. (2013). Exploring the ATP-binding site of P2X receptors. Front. Cell. Neurosci. 7:273. doi: 10.3389/fncel.2013. 00273

Chaumont, S., and Khakh, B. S. (2008). Patch-clamp coordinated spectroscopy shows $\mathrm{P} 2 \mathrm{X} 2$ receptor permeability dynamics require cytosolic domain rearrangements but not Panx-1 channels. Proc. Natl. Acad. Sci. U S A 105 , 12063-12068. doi: $10.1073 /$ pnas. 0803008105

Cheewatrakoolpong, B., Gilchrest, H., Anthes, J. C., and Greenfeder, S. (2005). Identification and characterization of splice variants of the human $\mathrm{P}_{2} \mathrm{X}_{7}$ ATP channel. Biochem. Biophys. Res. Commun. 332, 17-27. doi: 10.1016/j.bbrc.2005. 04.087

Chung, M.-K., Güler, A. D., and Caterina, M. J. (2008). TRPV1 shows dynamic ionic selectivity during agonist stimulation. Nat. Neurosci. 11, 555-564. doi: $10.1038 / \mathrm{nn} .2102$

Cockcroft, S., and Gomperts, B. D. (1979). ATP induces nucleotide permeability in rat mast cells. Nature 279, 541-542. doi: 10.1038/279541a0

Compan, V., Ulmann, L., Stelmashenko, O., Chemin, J., Chaumont, S., and Rassendren, F. (2012). P2X2 and P2X5 subunits define a new heteromeric receptor with P2X7-like properties. J. Neurosci. 32, 4284-4296. doi: 10.1523/JNEUROSCI.6332-11.2012

De Marchi, E., Orioli, E., Dal Ben, D., and Adinolfi, E. (2016). P2X7 receptor as a therapeutic target. Adv. Protein Chem. Struct. Biol. 104, 39-79. doi: 10.1016/bs. apcsb.2015.11.004

de Weille, J. R., Bassilana, F., Lazdunski, M., and Waldmann, R. (1998). Identification, functional expression and chromosomal localisation of a sustained human proton-gated cation channel. FEBS Lett. 433, 257-260. doi: 10.1016/s0014-5793(98)00916-8

Di Virgilio, F. (1995). The P2Z purinoceptor: an intriguing role in immunity, inflammation and cell death. Immunol. Today 16, 524-528. doi: 10.1016/01675699(95)80045-x

Di Virgilio, F., Dal Ben, D., Sarti, A. C., Giuliani, A. L., and Falzoni, S. (2017). The P2X7 receptor in infection and inflammation. Immunity 47, 15-31. doi: 10.1016/j.immuni.2017.06.020

Di Virgilio, F., Sarti, A. C., and Grassi, F. (2018). Modulation of innate and adaptive immunity by P2X ion channels. Curr. Opin. Immunol. 52, 51-59. doi: 10.1016/j.coi.2018.03.026

Ding, S., and Sachs, F. (1999). Single channel properties of P2X 2 purinoceptors. J. Gen. Physiol. 113, 695-720. doi: 10.1085/jgp.113.5.695

Duan, K., Yu, X., Zhang, C., and Zhou, Z. (2003). Control of secretion by temporal patterns of action potentials in adrenal chromaffin cells. J. Neurosci. 23, 11235-11243. doi: 10.1523/JNEUROSCI.23-35-11235.2003

Eickhorst, A. N., Berson, A., Cockayne, D., Lester, H. A., and Khakh, B. S. (2002). Control of $\mathrm{P}_{2} \mathrm{X}_{2}$ channel permeability by the cytosolic domain. J. Gen. Physiol. 120, 119-131. doi: 10.1085/jgp.20028535

Fujiwara, Y., and Kubo, Y. (2004). Density-dependent changes of the pore properties of the $\mathrm{P} 2 \mathrm{X}_{2}$ receptor channel. J. Physiol. 558, 31-43. doi: 10.1113 /jphysiol.2004.064568

Gordon, J. L. (1986). Extracellular ATP: effects, sources and fate. Biochem. J. 233, 309-319. doi: 10.1042/bj2330309

Gu, B. J., Rathsam, C., Stokes, L., McGeachie, A. B., and Wiley, J. S. (2009). Extracellular ATP dissociates nonmuscle myosin from $\mathrm{P}_{2} \mathrm{X}_{7}$ complex: this dissociation regulates $\mathrm{P}_{2} \mathrm{X}_{7}$ pore formation. Am. J. Physiol. Cell Physiol. 297, C430-C439. doi: 10.1152/ajpcell.00079.2009

Guerra, G. P., Rubin, M. A., and Mello, C. F. (2016). Modulation of learning and memory by natural polyamines. Pharmacol. Res. 112, 99-118. doi: 10.1016/j. phrs.2016.03.023

Habermacher, C., Dunning, K., Chataigneau, T., and Grutter, T. (2016a). Molecular structure and function of P2X receptors. Neuropharmacology 104 18-30. doi: 10.1016/j.neuropharm.2015.07.032

Habermacher, C., Martz, A., Calimet, N., Lemoine, D., Peverini, L., Specht, A., et al. (2016b). Photo-switchable tweezers illuminate pore-opening motions of an ATP-gated P2X ion channel. ELife 5:e11050. doi: 10.7554/eLife.11050

Han, X., Tomitori, H., Mizuno, S., Higashi, K., Füll, C., Fukiwake, T., et al. (2008). Binding of spermine and ifenprodil to a purified, soluble regulatory domain of the N-methyl-d-aspartate receptor. J. Neurochem. 107, 1566-1577. doi: 10.1111/j.1471-4159.2008.05729.x

Harkat, M., Peverini, L., Cerdan, A. H., Dunning, K., Beudez, J., Martz, A. et al. (2017). On the permeation of large organic cations through the pore of ATP-gated P2X receptors. Proc. Natl. Acad. Sci. U S A 114, E3786-E3795. doi: 10.1016/j.bpj.2016.11.22514

Hattori, M., and Gouaux, E. (2012). Molecular mechanism of ATP binding and ion channel activation in P2X receptors. Nature 485, 207-212. doi: $10.1038 /$ nature11010 
Heppel, L. A., Weisman, G. A., and Friedberg, I. (1985). Permeabilization of transformed cells in culture by external ATP. J. Membr. Biol. 86, 189-196. doi: 10.1007/bf01870597

Hiasa, M., Miyaji, T., Haruna, Y., Takeuchi, T., Harada, Y., Moriyama, S., et al. (2014). Identification of a mammalian vesicular polyamine transporter. Sci. Rep. 4:6836. doi: 10.1038/srep06836

Jiang, L.-H., Rassendren, F., Mackenzie, A., Zhang, Y. H., Surprenant, A., and North, R. A. (2005). N-methyl-D-glucamine and propidium dyes utilize different permeation pathways at rat $\mathrm{P}_{2} \mathrm{X}_{7}$ receptors. Am. J. Physiol. Cell Physiol. 289, C1295-C1302. doi: 10.1152/ajpcell.00253.2005

Karasawa, A., Michalski, K., Mikhelzon, P., and Kawate, T. (2017). The P2X7 receptor forms a dye-permeable pore independent of its intracellular domain but dependent on membrane lipid composition. Elife 6:e31186. doi: 10.7554/eLife.31186

Kawate, T., Michel, J. C., Birdsong, W. T., and Gouaux, E. (2009). Crystal structure of the ATP-gated P2X 4 ion channel in the closed state. Nature 460, 592-598. doi: 10.1038/nature08198

Khakh, B. S., and Alan North, R. (2006). P2X receptors as cell-surface ATP sensors in health and disease. Nature 442, 527-532. doi: 10.1038/nature04886

Khakh, B. S., and Egan, T. M. (2005). Contribution of transmembrane regions to ATP-gated $\mathrm{P}_{2} \mathrm{X}_{2}$ channel permeability dynamics. J. Biol. Chem. 280, 6118-6129. doi: 10.1074/jbc.M411324200

Khakh, B. S., Bao, X. R., Labarca, C., and Lester, H. A. (1999). Neuronal P2X transmitter-gated cation channels change their ion selectivity in seconds. Nat. Neurosci. 2, 322-330. doi: 10.1038/7233

Khakh, B. S., Fisher, J. A., Nashmi, R., Bowser, D. N., and Lester, H. A. (2005). An angstrom scale interaction between plasma membrane ATP-gated P2 $\mathrm{X}_{2}$ and $\alpha_{4} \beta_{2}$ nicotinic channels measured with fluorescence resonance energy transfer and total internal reflection fluorescence microscopy. J. Neurosci. 25, 6911-6920. doi: 10.1523/JNEUROSCI.0561-05.2005

Khakh, B. S., and Lester, H. A. (1999). Dynamic selectivity filters in ion channels. Neuron 23, 653-658. doi: 10.1016/s0896-6273(01)80025-8

Khakh, B. S., and North, R. A. (2012). Neuromodulation by extracellular ATP and P2X receptors in the CNS. Neuron 76, 51-69. doi: 10.1016/j.neuron.2012. 09.024

Kim, M., Jiang, L. H., Wilson, H. L., North, R. A., and Surprenant, A. (2001). Proteomic and functional evidence for a $\mathrm{P}_{2} \mathrm{X}_{7}$ receptor signalling complex. EMBO J. 20, 6347-6358. doi: 10.1093/emboj/20.22.6347

Kracun, S., Chaptal, V., Abramson, J., and Khakh, B. S. (2010). Gated access to the pore of a P2X receptor: structural implications for closed-open transitions. J. Biol. Chem. 285, 10110-10121. doi: 10.1074/jbc.M109.089185

Kurata, H. T., Marton, L. J., and Nichols, C. G. (2006). The polyamine binding site in inward rectifier $\mathrm{K}^{+}$channels. J. Gen. Physiol. 127, 467-480. doi: 10.1085/jgp. 200509467

Lemoine, D., Jiang, R., Taly, A., Chataigneau, T., Specht, A., and Grutter, T. (2012). Ligand-gated ion channels: new insights into neurological disorders and ligand recognition. Chem. Rev. 112, 6285-6318. doi: 10.1021/cr3000829

Li, M., Chang, T.-H., Silberberg, S. D., and Swartz, K. J. (2008). Gating the pore of P2X receptor channels. Nat. Neurosci. 11, 883-887. doi: 10.1038/nn.2151

Li, M., Kawate, T., Silberberg, S. D., and Swartz, K. J. (2010). Poreopening mechanism in trimeric P2X receptor channels. Nat. Commun. 1:44. doi: $10.1038 /$ ncomms 1048

Li, M., Toombes, G. E. S., Silberberg, S. D., and Swartz, K. J. (2015). Physical basis of apparent pore dilation of ATP-activated P2X receptor channels. Nat. Neurosci. 18, 1577-1583. doi: 10.1038/nn.4120

Lingueglia, E., de Weille, J. R., Bassilana, F., Heurteaux, C., Sakai, H., Waldmann, R., et al. (1997). A modulatory subunit of acid sensing ion channels in brain and dorsal root ganglion cells. J. Biol. Chem. 272, 29778-29783. doi: 10.1074/jbc.272.47.29778

Lucifora, S., Willcockson, H. H., Lu, C.-R., Darstein, M., Phend, K. D., Valtschanoff, J. G., et al. (2006). Presynaptic low- and high-affinity kainate receptors in nociceptive spinal afferents. Pain 120, 97-105. doi: 10.1016/j.pain. 2005.10.018

Madeo, F., Eisenberg, T., Pietrocola, F., and Kroemer, G. (2018). Spermidine in health and disease. Science 359:eaan2788. doi: 10.1126/science.aan2788

Mansoor, S. E., Lü, W., Oosterheert, W., Shekhar, M., Tajkhorshid, E., and Gouaux, E. (2016). X-ray structures define human $\mathrm{P}_{2} \mathrm{X}_{3}$ receptor gating cycle and antagonist action. Nature 538, 66-71. doi: 10.1038/nature19367
Marques-da-Silva, C., Chaves, M., Castro, N., Coutinho-Silva, R., and Guimaraes, M. (2011). Colchicine inhibits cationic dye uptake induced by ATP in $\mathrm{P} 2 \mathrm{X} 2$ and $\mathrm{P} 2 \mathrm{X} 7$ receptor-expressing cells: implications for its therapeutic action. Br. J. Pharmacol. 163, 912-926. doi: 10.1111/j.1476-5381. 2011.01254.x

Mony, L., Zhu, S., Carvalho, S., and Paoletti, P. (2011). Molecular basis of positive allosteric modulation of GluN2B NMDA receptors by polyamines. EMBO J. 30, 3134-3146. doi: 10.1038/emboj.2011.203

Mourot, A., Fehrentz, T., Le Feuvre, Y., Smith, C. M., Herold, C., Dalkara, D., et al. (2012). Rapid optical control of nociception with an ion-channel photoswitch. Nat. Methods 9, 396-402. doi: 10.1038/nmeth.1897

Murrell-Lagnado, R. D. (2017). Regulation of P2X purinergic receptor signaling by cholesterol. Curr. Top. Membr. 80, 211-232. doi: 10.1016/bs.ctm.2017. 05.004

Nabissi, M., Morelli, M. B., Santoni, M., and Santoni, G. (2013). Triggering of the TRPV2 channel by cannabidiol sensitizes glioblastoma cells to cytotoxic chemotherapeutic agents. Carcinogenesis 34, 48-57. doi: 10.1093/carcin/ bgs 328

Nicke, A., Kuan, Y.-H., Masin, M., Rettinger, J., Marquez-Klaka, B., Bender, O., et al. (2009). A functional P2X7 splice variant with an alternative transmembrane domain 1 escapes gene inactivation in P2X7 knock-out mice. J. Biol. Chem. 284, 25813-25822. doi: 10.1074/jbc.M109.033134

North, R. A. (2002). Molecular physiology of P2X receptors. Physiol. Rev. 82, 1013-1067. doi: 10.1152/physrev.00015.2002

Nuttle, L. C., and Dubyak, G. R. (1994). Differential activation of cation channels and non-selective pores by macrophage $\mathrm{P} 2_{\mathrm{z}}$ purinergic receptors expressed in Xenopus oocytes. J. Biol. Chem. 269, 13988-13996.

Pelegrin, P., and Surprenant, A. (2006). Pannexin-1 mediates large pore formation and interleukin- $1 \beta$ release by the $\mathrm{ATP}$-gated $\mathrm{P}_{2} \mathrm{X}_{7}$ receptor. EMBO J. 25, 5071-5082. doi: 10.1038/sj.emboj.7601378

Pellegatti, P., Falzoni, S., Pinton, P., Rizzuto, R., and Di Virgilio, F. (2005). A novel recombinant plasma membrane-targeted luciferase reveals a new pathway for ATP secretion. Mol. Biol. Cell 16, 3659-3665. doi: 10.1091/mbc.e05-03-0222

Perrais, D., Veran, J., and Mulle, C. (2010). Gating and permeation of kainate receptors: differences unveiled. Trends Pharmacol. Sci. 31, 516-522. doi: 10.1016/j.tips.2010.08.004

Pippel, A., Stolz, M., Woltersdorf, R., Kless, A., Schmalzing, G., and Markwardt, F. (2017). Localization of the gate and selectivity filter of the full-length P2X7 receptor. Proc. Natl. Acad. Sci. U S A 114, E2156-E2165. doi: 10.1073/pnas.1610414114

Pougnet, J.-T., Toulme, E., Martinez, A., Choquet, D., Hosy, E., and BouéGrabot, E. (2014). ATP P2X receptors downregulate AMPA receptor trafficking and postsynaptic efficacy in hippocampal neurons. Neuron 83, 417-430. doi: 10.1016/j.neuron.2014.06.005

Puopolo, M., Binshtok, A. M., Yao, G.-L., Oh, S. B., Woolf, C. J., and Bean, B. P. (2013). Permeation and block of TRPV1 channels by the cationic lidocaine derivative QX-314. J. Neurophysiol. 109, 1704-1712. doi: 10.1152/jn. 00012.2013

Rassendren, F., Buell, G. N., Virginio, C., Collo, G., North, R. A., and Surprenant, A. (1997). The permeabilizing ATP receptor, P2X 7 . Cloning and expression of a human cDNA. J. Biol. Chem. 272, 5482-5486. doi: 10.1074/jbc. 272.9.5482

Riedel, T., Lozinsky, I., Schmalzing, G., and Markwardt, F. (2007a). Kinetics of $\mathrm{P}_{2} \mathrm{X}_{7}$ receptor-operated single channels currents. Biophys. J. 92, 2377-2391. doi: 10.1529/biophysj.106.091413

Riedel, T., Schmalzing, G., and Markwardt, F. (2007b). Influence of extracellular monovalent cations on pore and gating properties of $\mathrm{P}_{2} \mathrm{X}_{7}$ receptor-operated single-channel currents. Biophys. J. 93, 846-858. doi: 10.1529/biophysj.106. 103614

Rokic, M. B., and Stojilkovic, S. S. (2013). Two open states of P2X receptor channels. Front. Cell. Neurosci. 7:215. doi: 10.3389/fncel.2013.00215

Saul, A., Hausmann, R., Kless, A., and Nicke, A. (2013). Heteromeric assembly of P2X subunits. Front. Cell. Neurosci. 7:250. doi: 10.3389/fncel.2013.00250

Savio, L. E. B., de Andrade Mello, P., da Silva, C. G., and Coutinho-Silva, R. (2018). The P2X7 receptor in inflammatory diseases: angel or demon? Front. Pharmacol. 9:52. doi: 10.3389/fphar.2018.00052

Sluyter, R. (2017). The P2X7 receptor. Adv. Exp. Med. Biol. 1051, 17-53. doi: 10.1007/5584_2017_59 
Solini, A., Cuccato, S., Ferrari, D., Santini, E., Gulinelli, S., Callegari, M. G., et al. (2008). Increased $\mathrm{P} 2 \mathrm{X}_{7}$ receptor expression and function in thyroid papillary cancer: a new potential marker of the disease? Endocrinology 149, 389-396. doi: 10.1210/en.2007-1223

Sorge, R. E., Trang, T., Dorfman, R., Smith, S. B., Beggs, S., Ritchie, J., et al. (2012). Genetically determined P2X7 receptor pore formation regulates variability in chronic pain sensitivity. Nat. Med. 18, 595-599. doi: 10.1038/ $\mathrm{nm} .2710$

Stanchev, D., Blosa, M., Milius, D., Gerevich, Z., Rubini, P., Schmalzing, G., et al. (2009). Cross-inhibition between native and recombinant TRPV1 and $\mathrm{P} 2 \mathrm{X}_{3}$ receptors. Pain 143, 26-36. doi: 10.1016/j.pain.2009.01.006

Steinberg, T. H., Newman, A. S., Swanson, J. A., and Silverstein, S. C. (1987). ATP4-permeabilizes the plasma membrane of mouse macrophages to fluorescent dyes. J. Biol. Chem. 262, 8884-8888.

Steinberg, T. H., and Silverstein, S. C. (1989). "Chapter 3 ATP permeabilization of the plasma membrane," in Methods in Cell Biology, ed. A. M. Tartakoff (New York, NY: Academic Press), 45-61.

Stephan, G., Huang, L., Tang, Y., Vilotti, S., Fabbretti, E., Yu, Y., et al. (2018). The ASIC3/P2X3 cognate receptor is a pain-relevant and ligandgated cationic channel. Nat. Commun. 9:1354. doi: 10.1038/s41467-01803728-5

Suadicani, S. O., Brosnan, C. F., and Scemes, E. (2006). $\mathrm{P}_{2} \mathrm{X}_{7}$ receptors mediate ATP release and amplification of astrocytic intercellular $\mathrm{Ca}^{2+}$ signaling. J. Neurosci. 26, 1378-1385. doi: 10.1523/JNEUROSCI.3902-05.2006

Surprenant, A., Rassendren, F., Kawashima, E., North, R. A., and Buell, G. (1996). The cytolytic $\mathrm{P}_{2 Z}$ receptor for extracellular ATP identified as a $\mathrm{P}_{2 \mathrm{X}}$ receptor $\left(\mathrm{P} 2 \mathrm{X}_{7}\right)$. Science 272, 735-738.

Swayne, L. A., and Boyce, A. K. J. (2017). Regulation of pannexin 1 surface expression by extracellular ATP: potential implications for nervous system function in health and disease. Front. Cell. Neurosci. 11:230. doi: 10.3389/fncel. 2017.00230

Takeuchi, T., Harada, Y., Moriyama, S., Furuta, K., Tanaka, S., Miyaji, T., et al. (2017). Vesicular polyamine transporter mediates vesicular storage and release of polyamine from mast cells. J. Biol. Chem. 292, 3909-3918. doi: 10.1074/jbc. M116.756197

Tochitsky, I., Helft, Z., Meseguer, V., Fletcher, R. B., Vessey, K. A., Telias, M., et al. (2016). How azobenzene photoswitches restore visual responses to the blind retina. Neuron 92, 100-113. doi: 10.1016/j.neuron.2016.08.038
Valera, S., Hussy, N., Evans, R. J., Adami, N., North, R. A., Surprenant, A., et al. (1994). A new class of ligand-gated ion channel defined by P2X receptor for extracellular ATP. Nature 371, 516-519. doi: 10.1038/371516a0

Virginio, C., MacKenzie, A., North, R. A., and Surprenant, A. (1999a). Kinetics of cell lysis, dye uptake and permeability changes in cells expressing the rat $\mathrm{P}_{2} \mathrm{X}_{7}$ receptor. J. Physiol. 519, 335-346. doi: 10.1111/j.1469-7793.1999. 0335m.x

Virginio, C., MacKenzie, A., Rassendren, F. A., North, R. A., and Surprenant, A. (1999b). Pore dilation of neuronal P2X receptor channels. Nat. Neurosci. 2, 315-321. doi: 10.1038/7225

Wei, L., Caseley, E., Li, D., and Jiang, L.-H. (2016). ATP-induced P2X receptordependent large pore formation: how much do we know? Front. Pharmacol. 7:5. doi: 10.3389/fphar.2016.00005

Xu, X. J., Boumechache, M., Robinson, L. E., Marschall, V., Gorecki, D. C., Masin, M., et al. (2012). Splice variants of the P2X7 receptor reveal differential agonist dependence and functional coupling with pannexin-1. J. Cell Sci. 125, 3776-3789. doi: 10.1242/jcs.099374

Yan, Z., Li, S., Liang, Z., Tomić, M., and Stojilkovic, S. S. (2008). The P2X 7 receptor channel pore dilates under physiological ion conditions. J. Gen. Physiol. 132, 563-573. doi: 10.1085/jgp.200810059

Young, M. T., Pelegrin, P., and Surprenant, A. (2006). Identification of $\mathrm{Thr}_{283}$ as a key determinant of $\mathrm{P}_{2} \mathrm{X}_{7}$ receptor function. Br. J. Pharmacol. 149, 261-268. doi: 10.1038/sj.bjp.0706880

Zubcevic, L., Le, S., Yang, H., and Lee, S.-Y. (2018). Conformational plasticity in the selectivity filter of the TRPV2 ion channel. Nat. Struct. Mol. Biol. 25, 405-415. doi: 10.1038/s41594-018-0059-Z

Conflict of Interest Statement: The authors declare that the research was conducted in the absence of any commercial or financial relationships that could be construed as a potential conflict of interest.

Copyright (c) 2018 Peverini, Beudez, Dunning, Chataigneau and Grutter. This is an open-access article distributed under the terms of the Creative Commons Attribution License (CC BY). The use, distribution or reproduction in other forums is permitted, provided the original author(s) and the copyright owner(s) are credited and that the original publication in this journal is cited, in accordance with accepted academic practice. No use, distribution or reproduction is permitted which does not comply with these terms. 